\title{
PERANCANGAN DAN PEMBUATAN SMART TRASH BIN BERBASIS ARDUINO UNO DI UNIVERSITAS MAARIF HASYIM LATIF
}

\author{
Sukarjadi $^{1}$, Deby Tobagus Setiawan ${ }^{2}$, Arifiyanto $^{3}$, Moch. Hatta ${ }^{4}$ \\ 1Teknik Elektro \\ Politeknik Sakti, Surabaya, Indonesia \\ e-mail : sukaryadisakti@gmail.com \\ 2,3,4Teknik Komputer, Fakultas Teknik \\ Universitas Maarif Hasyim Latif, Sidoarjo, Indonesia \\ e-mail : 2tobagus26@gmail.com, ${ }^{3}$ arifiyanto15@gmail.com, ${ }^{4}$ moch.hatta@dosen.umaha.ac.id \\ Diterima: 25 Oktober 2017. Disetujui : 25 Nopember 2017. Dipublikasikan : 4 Desember 2017 \\ (C)2017 -TESJ Fakultas Teknik Universitas Maarif Hasyim Latif. Ini adalah artikel dengan \\ akses terbuka di bawah lisensi CC BY 4.0 (https://creativecommons.org/licenses/by/4.0/)
}

\begin{abstract}
ABSTRAK
Dalam meningkatkan kesadaran akan kepedulian terhadap kebersihan lingkungan, kadang memerlukan cara yang unik agar tiap-tiap individu tertarik, sehingga tak segan untuk membuang sampah pada tempatnya. Tempat sampah pada umumnya membuka dan menutupnya secara manual. Hal ini menyulitkan seseorang untuk membuang sampah ataupun membersihkan sampah yang sudah penuh.

Penelitian ini dilakukan di Universitas Maarif Hasyim Latif, memberikan solusi dengan membuat tempat sampah pintar (smart trash bin) berbasis Arduino Uno, menggunakan sensor HC-SR04, motor servo, rangkaian adaptor, buzzer dan LED. Dalam Smart Trash Bin menggunakan sensor HC-SR04 berbasis Arduino board sebagai pendeteksi jarak, sedangkan motor servo digunakan sebagai penggerak buka dan tutup tempat sampah, dan buzzer beserta LED sebagai notifikasi bahwa sampah sudah penuh.

Perancangan modul yang dilakukan dalam tiga tahap : (1) perancangan software mulai dari pendeskripsian kerja dari sistem Arduino Uno, bahasa c++ sebagai bahasa perancangan program, pembuatan flowchart, Selanjutnya masuk kedalam pembuatan program pada komputer; (2) perencanaan hardware yang dilakukan pada pembuatan rangkaian modul sensor jarak, LED dan buzzer; dan (3) pembandingan antara hardware dan software.
\end{abstract}

Kata Kunci : Arduino Uno, Arduino IDE, trash bin, bahasa c++, Sensor jarak HC-SR04, Servo

\section{PENDAHULUAN}

Manusia merupakan makhluk hidup yang menginginkan segala sesuatu yang tampak bersih dan indah, salah satunya kebersihan lingkungan. Banyak manusia yang sadar dan banyak pula yang belum sadar akan kepeduliannya terhadap kebersihan lingkungan di sekitarnya, hal tersebut dapat direfleksikan seperti masih banyaknya sampah yang berceceran di jalan dan juga di taman kota. Keadaan tersebut tentunya meresahkan bagi pengguna fasilitas public, tak terkecuali di Universitas Maarif Hasyim Latif.

Tempat sampah yang sudah disediakan oleh instansi kebersihan hanya menjadi hiasan bisu di jalanan yang tidak terurus dan tidak menarik. Mungkin hal tersebut juga menjadi faktor yang menyebabkan manusia tidak mau untuk membuang sampah. Berkaca dari hal tersebut kesadaran se- tiap individu akan kebersihan lingkungan sangat diperlukan dan lebih ditingkatkan.

Dalam meningkatkan kesadaran akan kepedulian terhadap kebersihan lingkungan, kadang memerlukan cara yang unik agar tiap-tiap individu tertarik, sehingga tak segan untuk membuang sampah pada tempatnya. Cara unik tersebut yaitu dengan membuat tempat sampah pintar (Smart Trash Bin). Ini adalah sebuah tempat sampah pintar untuk sampah kering yang tutup tempat sampahnya dapat terbuka sendiri dan ketika sampah sudah dimasukkan serta tutup tempat sampah tertutup dengan sendirinya.

\section{Mikrokontroler}

Mikrokontroler merupakan bentuk sederhana dari sebuah sistem komputer yang dikemas di dalam sebuah chip, di dalam mikrokontroler sudah terdapat beberapa sistem yang mendukung mikrokontroler dapat bekerja meliputi mikrokontroler 
itu sendiri, ROM, RAM, I/O dan clock seperti halnya yang dimiliki oleh sebuah komputer PC. Di dalam chip mikrokontroler yang kecil telah ditanamkan sebuah sistem yang dapat digunakan sebagai prosesor yang memiliki fitur yang dapat disamakan dengan sistem komputer. Perkembangan mikrokontroler sangat mendukung perkembangan sistem kendali otomatis dari suatu device atau pirantipiranti pengontrol suatu alat yang tidak dapat berdiri sendiri (stand alone), sehingga mikrokontroler yang dapat mendukung sebagai pengendali otomatis tersebut.

\section{Arduino Board}

Merupakan pengendali mikro single-board yang bersifat open-source, diturunkan dari Wiring platform, dirancang untuk memudahkan penggunaan elektronik dalam berbagai bidang. Dibagian hardware memiliki prosesor Atmel AVR dan dibagian softwarenya memiliki bahasa pemrograman sendiri. Saat ini Arduino sangat populer di seluruh dunia.

Banyak pemula yang belajar mengenal robotika dan elektronika lewat Arduino karena mudah dipelajari. Para pemula atau profesional pun ikut senang mengembangkan aplikasi elektronik menggunakan Arduino. Bahasa yang dipakai dalam Arduino bukan assembler yang relatif sulit, tetapi bahasa C yang disederhanakan dengan bantuan pustaka-pustaka (libraries) Arduino. Arduino juga menyederhanakan proses bekerja dengan mikrokontroler.

\section{Arduino IDE}

IDE itu merupakan kependekan dari Integrated Developtment Enviroenment, atau secara bahasa mudahnya merupakan lingkungan terintegrasi yang digunakan untuk melakukan pengembangan. Disebut sebagai lingkungan karena melalui software inilah Arduino dilakukan pemrograman untuk melakukan fungsi-fungsi yang dibenamkan melalui sintaks pemrograman.

Arduino menggunakan bahasa pemrograman sendiri yang menyerupai bahasa C. Bahasa pemrograman Arduino (Sketch) sudah dilakukan perubahan untuk memudahkan pemula dalam melakukan pemrograman dari bahasa aslinya. Sebelum dijual ke pasaran, IC mikrokontroler Arduino telah ditanamkan suatu program bernama Bootlader yang berfungsi sebagai penengah antara compiler Arduino dengan mikrokontroler.

Arduino IDE dibuat dari bahasa pemrograman JAVA. Arduino IDE juga dilengkapi dengan library $\mathrm{C} / \mathrm{C}++$ yang biasa disebut Wiring yang membuat operasi INPUT dan OUTPUT menjadi lebih mudah. Arduino IDE ini dikembangkan dari software Processing yang dirombak menjadi Arduino IDE khusus untuk pemrograman dengan Arduino.

\section{Stuktur program Arduino IDE}

Secara umum, struktur program pada arduino dapat dibagi menjadi 2 bagian yaitu setup dan loop.

a. Bagian setup adalah bagian yang merupakan area menempatkan kode-kode inialisasi sistem sebelum masuk ke dalam bagian loop (body). Secara prinsip, setup merupakan bagian yang dieksekusi hanya sekali yaitu pada saat program dimulai (Start). Jadi bagian ini merupakan bagian yang penting pada pemrograman arduino karena mencakup kode-kode yang mempengaruhi body program nantinya.

b. Bagian loop adalah bagian yang merupakan inti utama dari program Arduino. Perintah-perintah yang dituliskan dalam bentuk baris-baris program akan diulangi secara terus-menerus. Perintah utama yang ingin diperintahkan kepada sistem dapat dimuat di area ini.

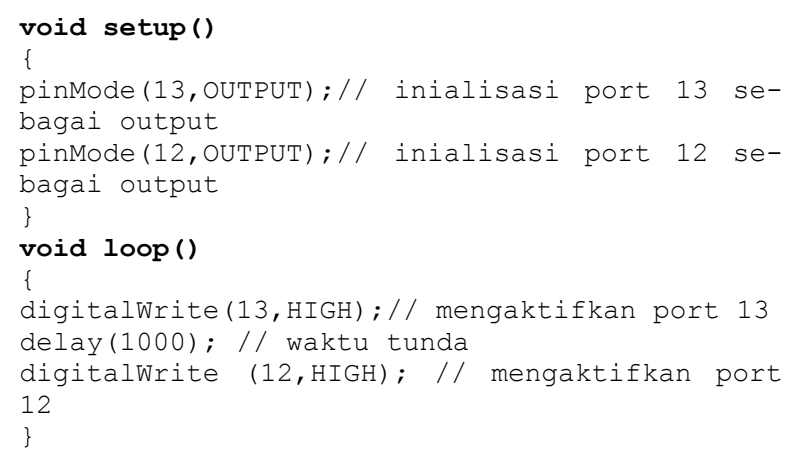

Berdasarkan contoh di atas, dapat dilihat kedua struktur utama dari program Arduino.

Jika diperhatikan dengan seksama, ternyata area setup dan loop memiliki kesamaan yaitu dimulai oleh tanda \{ dan diakhiri oleh tanda $\}$. Perlu diperhatikan juga bagaimana penulisan void setup maupun void loop nya. Perhatikan tanda () setelah penulisan void setup dan void loop. Hal-hal tersebut merupakan hal yang perlu diperhatikan dari segi penulisan struktur utama dari pemrograman Arduino.

Secara prinsip, bagian void setup hanya akan dieksekusi satu kali. Hal ini berarti jika melihat pada baris program di atas, maka inialisasi port 13 dan 12 hanya akan dilakukan satu kali yaitu ketika program mulai dijalankan. Sedangkan untuk baris program yang berada pada void loop port 13 dan 12 akan terus diaktifkan bergantian dengan waktu delay.

\section{Sensor HC-SR04}

Sensor ultrasonik adalah sebuah sensor yang berfungsi untuk mengubah besaran fisis (bunyi) menjadi besaran listrik dan sebaliknya. Cara kerja sensor ini didasarkan pada prinsip dari pantulan suatu gelombang suara sehingga dapat 
dipakai untuk menafsirkan eksistensi (jarak) suatu benda dengan frekuensi tertentu. Disebut sebagai sensor ultrasonik karena sensor ini menggunakan gelombang ultrasonik (bunyi ultrasonik).

Secara umum, alat ini akan menembakkan gelombang ultrasonik menuju suatu area atau suatu target. Setelah gelombang menyentuh permukaan target, maka target akan memantulkan kembali gelombang tersebut. Gelombang pantulan dari target akan ditangkap oleh sensor, kemudian sensor menghitung selisih antara waktu pengiriman gelombang dan waktu gelombang pantul diterima.

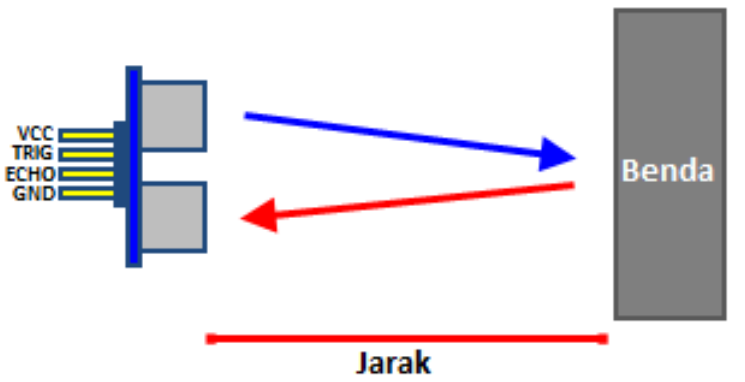

Gambar 1. Sensor HC-SR04

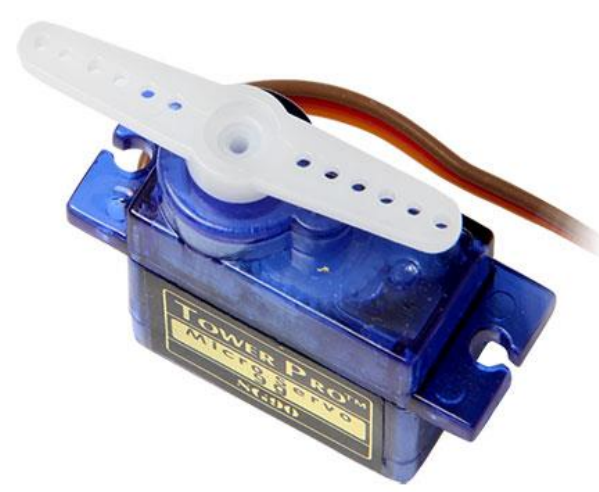

Gambar 2. Motor Servo 180

\section{Motor Servo}

Motor servo adalah sebuah perangkat atau aktuator putar (motor) yang dirancang dengan sistem kontrol umpan balik loop tertutup (servo), sehingga dapat di set-up atau di atur untuk menentukan dan memastikan posisi sudut dari poros output motor. Motor servo merupakan perangkat yang terdiri dari motor DC, serangkaian gear, rangkaian kontrol dan potensiometer. Serangkaian gear yang melekat pada poros motor DC akan memperlambat putaran poros dan meningkatkan torsi motor servo, sedangkan potensiometer dengan perubahan resistansinya saat motor berputar berfungsi sebagai penentu batas posisi putaran poros motor servo.

Penggunaan sistem kontrol loop tertutup pada motor servo berguna untuk mengontrol gerakan dan posisi akhir dari poros motor servo. Ada dua jenis motor servo, yaitu motor servo AC dan DC. Motor servo AC lebih dapat menangani arus yang tinggi atau beban berat, sehingga sering diaplikasikan pada mesin-mesin industri. Sedangkan motor servo DC biasanya lebih cocok untuk digunakan pada aplikasi-aplikasi yang lebih kecil. Dan bila dibedakan menurut rotasinya, umumnya terdapat dua jenis motor servo, yaitu motor servo rotation $180^{\circ}$ dan servo rotation continuous.

1. Motor servo standard (servo rotation $180^{\circ}$ ) Motor mervo $180^{\circ}$ adalah jenis yang paling umum dari motor servo, dimana putaran poros outputnya terbatas hanya $90^{\circ}$ kearah kanan dan $90^{\circ}$ kearah kiri. Dengan kata lain total putarannya hanya setengah lingkaran atau $180^{\circ}$.

2. Motor servo rotation continuous merupakan jenis motor servo yang sebenarnya sama dengan jenis servo standard, hanya saja perputaran porosnya tanpa batasan atau dengan kata lain dapat berputar terus, baik ke arah kanan maupun kiri

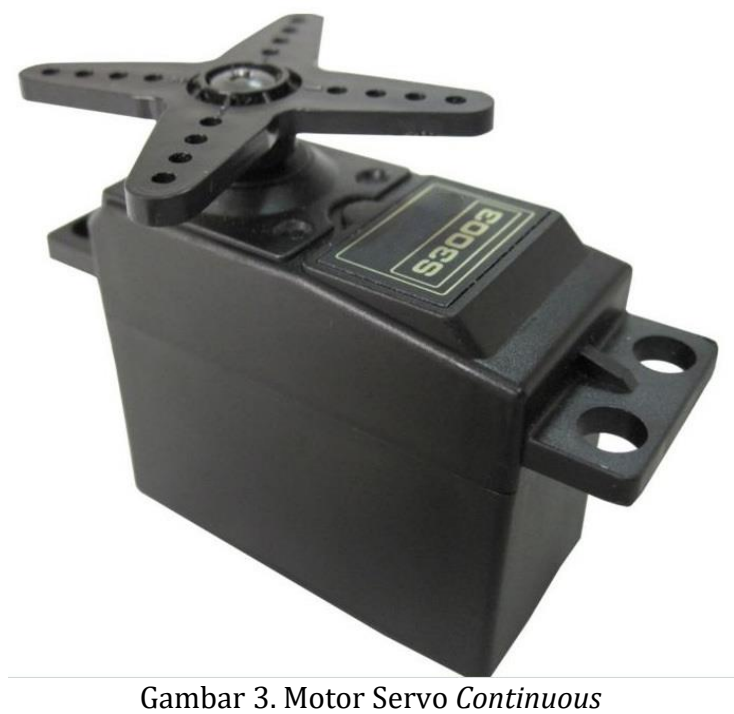

\section{Buzzer}

Buzzer adalah sebuah komponen elektronika yang dapat mengubah sinyal listrik menjadi getaran suara. Pada umumnya, buzzer yang merupakan sebuah perangkat audio ini sering digunakan pada rangkaian anti maling, alarm pada jam tangan, bel rumah, peringatan mundur pada truk dan perangkat peringatan bahaya lainnya. Jenis buzzer yang sering ditemukan dan digunakan adalah buzzer yang berjenis piezoelectric.

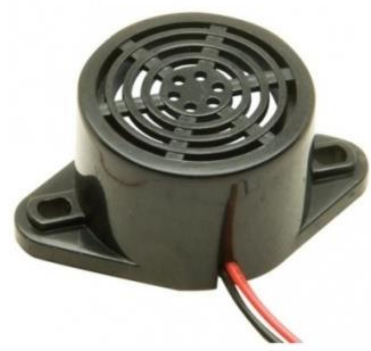

Gambar 4. Buzzer 
Hal ini dikarenakan buzzer piezoelectric memiliki berbagai kelebihan seperti lebih murah, relatif lebih ringan dan lebih mudah dalam menggabungkannya ke rangkaian elektronika lainnya. Buzzer yang termasuk dalam keluarga transduser ini juga sering disebut dengan beeper.

\section{LED (Light Emitting Diode)}

Merupakan komponen atau rangkaian elektronika yang bias memancarkan cahaya monokromatik saat diberi tegangan maju. LED adalah golongan keluarga diode yang dibuat dari bahan semikonduktor. Dan warna dari cahaya yang dipancarkan oleh LED ini sangat tergantung dengan jenis bahan semikonduktor yang digunakan.

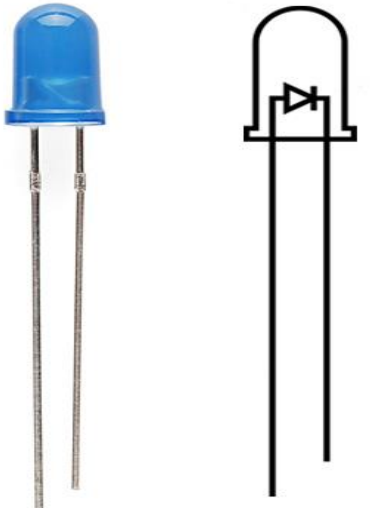

Gambar 5. LED (Light Emitting Diode)

LED terdiri dari sebuah chip semikonduktor yang ditambah sehingga menciptakan junction $\mathrm{P}$ dan N. Yang dimaksud dengan proses tambahan dalam semikonduktor adalah proses untuk menambahkan ketidakmurnian (impurity) pada semikonduktor yang murni sehingga menghasilkan karakteristik kelistrikan yang diinginkan. Ketika LED dialiri tegangan maju atau bias forward yaitu dari Anoda (P) menuju ke Katoda (K), kelebihan elektron pada N-Type material akan berpindah ke wilayah yang kelebihan hole (lubang) yaitu wilayah yang bermuatan positif (P-Type material). Saat elektron berjumpa dengan hole akan melepaskan photon dan memancarkan cahaya monokromatik (satu warna).

\section{METODE PENELITIAN}

Bentuk fisik Smart Trash Bin. Dari keseluruhan dimensi Smart Trash Bin memiliki ukuran tinggi $70 \mathrm{~cm}$ lebar $35 \mathrm{~cm}$. Mekanik buka dan tutup otomatis dengan ukuran panjang $32 \mathrm{~cm}$ dan lebar $10 \mathrm{~cm}$, sedangkan untuk pintu pembuangan sampah jika penuh memiliki ukuran tinggi $50 \mathrm{~cm}$ lebar $32 \mathrm{~cm}$.

\section{Blok Diagram Perencanaan Hardware}

Perencanaan merupakan tahapan penting dalam pembahasan suatu penelitian. Perencanaan ini meliputi spesifikasi komponen yang terdapat pada rangkaian tersebut. Adapun tujuan dari perencanaan hardware adalah untuk menghasilkan alat yang sesuai spesifikasi yang diharapkan dengan memperhatikan hal hal yang mendukung dalam merealisasikan alat tersebut dengan meminimalisir kesalahan-kesalahan yang mungkin rerjadi.

Langkah awal dari perencanaan hardware ini adalah membuat blok diagram dari hardware yang akan dibuat. Tujuannya adalah untuk mempermudah menganalisa hubungan komponenkomponen antara satu blok ataupun dengan blok yang lainnya agar bisa mengetahui dengan jelas. Berikut adalah blok diagram hardware untuk smart trash bin menggunakan sensor dan motor servo berbasis arduino board.

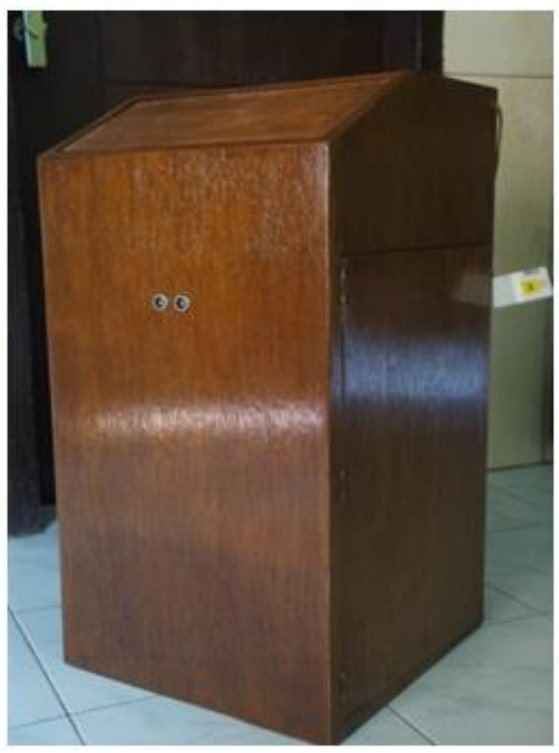

Gambar 6. Bentuk Fisik Smart Trash Bin

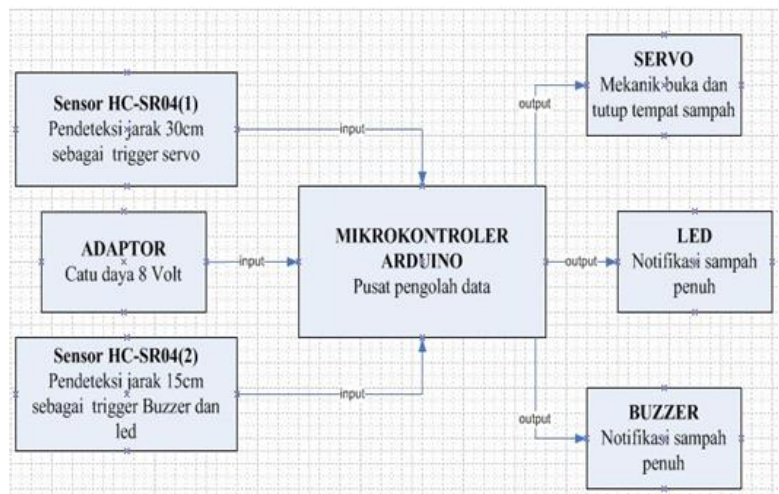

Gambar 7. Blok Diagram Perencanaan Hardware

Secara umum cara kerja rangkaian ini dapat dilihat pada Gambar 7, penjelasan dari tiap blok gambar tersebut adalah sebagai berikut :

a. Adaptor

Berfungsi sebagai catu daya semua komponen 
b. Sensor HC-SR04

Bagian ini berfungsi sebagai alat input. Sensor HC-SR04 dimanfaatkan untuk mendeteksi adanya jarak mendekat.

c. Mikrokontroler Arduino Board

Mikrokontroler Arduino board berfungsi sebagai pusat pengolah data atau dapat dikatakan sebagai CPU (Central Proccesing Unit), yang mana tugasnya mengolah semua data yang masuk dan data yang keluar. Bagian ini akan memeriksa input dari sensor HC-SR04 berupa sinyal ultrasonik mendeteksi adanya objek mendekat, dan memberikan perintah ke bagian motor servo.

d. Motor Servo

Motor Servo berfungsi sebagai penggerak buka dan tutup tempat sampah.

e. Buzzer

Buzzer berfungsi sebagai notifikasi suara. Prinsip dari buzzer sendiri akan bekerja sebagai notifikasi suara ketika keadaan sensor HC-SR04 mendeteksi jarak tumpukkan sampah hampir penuh.

f. LED

LED (Light Emitting Diode) sebagai notifikasi berupa pancaran cahaya monokromatik ketika diberikan tegangan maju. Prinsip dari LED sendiri sama halnya buzzer sebagai notifikasi suara ketika keadaan Sensor HC-SR04 mendeteksi jarak tumpukkan sampah hampir penuh.

\section{Perencanaan Perangkat Lunak}

Sebelum membuat perangkat lunak, terlebih dahulu dibuat diagram alur (flowchart) program agar menghasilkan program yang sesuai dengan tujuan yang diharapkan.

Sistem memliki dua komponen input, dan tiga komponen output. Komponen input adalah dua buah sensor ultrasonik dan komponen otput adalah motor servo, buzzer dan LED. Sensor ultrasonik pertama digunakan untuk mendeteksi kehadiran orang yang ingin membuang sampah. Sensor ultrasonik pertama ini diletakkan diluar tempat sampah. Jadi ketika sensor ultrasonik pertama mendeteksi kehadiran benda dengan jarak lebih kecil atau sama dengan $20 \mathrm{~cm}$, maka akan ada perintah untuk mengeluarkan output berupa gerakan motor servo, yaitu membuka tempat sampah. Tutup tempat sampah akan menutup lagi jika jarak yang dibaca oleh sensor sudah lebih dari 20 $\mathrm{cm}$. Sensor ultrasonik kedua diletakkan didalam, tepatnya bagian atas, dari tempat sampah. Sensor ultrasonik kedua ini akan mengukur jarak dari ujung tempat sampah. Jika jarak yang dibaca oleh sensor berubah dalam waktu yang lama yang menandakan tempat sampah telah penuh, maka akan ada output berupa suara buzzer berbunyi disertai lampu LED menyala. Adapun metode pemeriksaan input dilakukan dengan intrupsi se- tiap 2 milisekon. Jika terjadi perubahan input pada saat intrupsi tersebut, maka kondisi-kondisi konsekuensi dari input yang telah dijelaskan di atas akan diaplikasikan

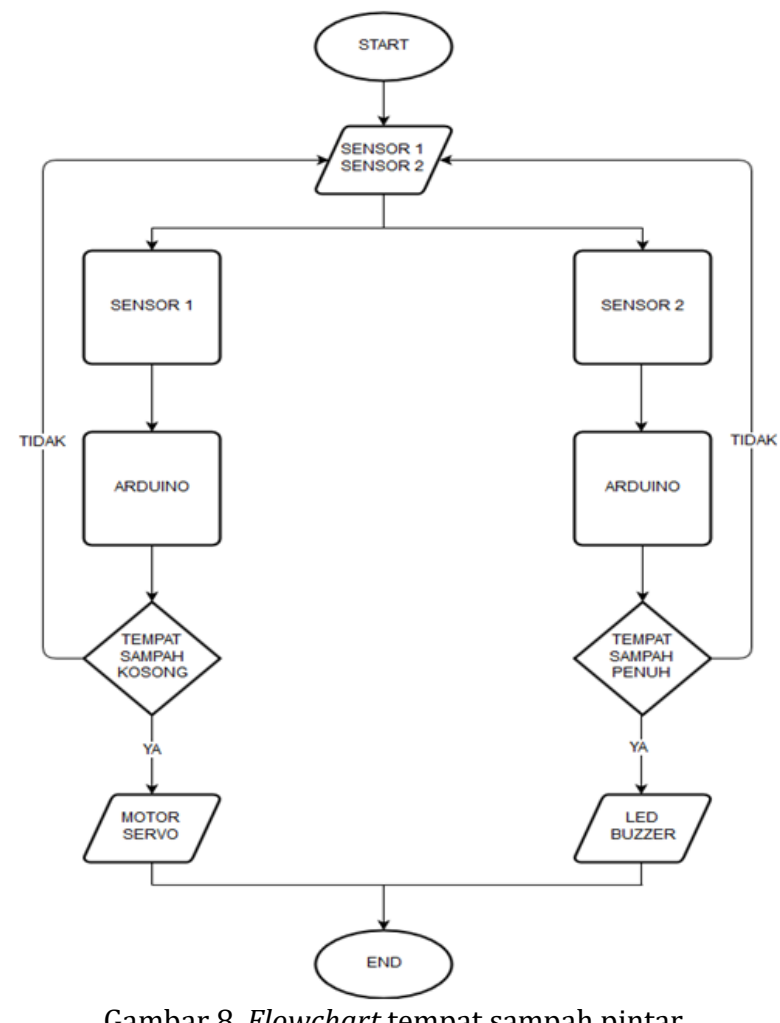

Gambar 8. Flowchart tempat sampah pintar (smart trash bin)

\section{Program SMART TRASH BIN pada Arduino}

Agar Arduino board bisa digunakan maka yang perlu dilakukan adalah memasukkan program Arduino tersebut menggunakan software Arduino IDE. Adapun script yang digunakan untuk program Arduino board tercantum dalam lampiran.

\section{HASIL DAN PEMBAHASAN}

\section{Pengujian Software}

Untuk membuktikan semua sistem sudah berjalan sebagaimana mestinya. Peralatan yang digunakan adalah sebagai berikut : modul rangkaian mikrokontroler, buzzer, LED, 2x sensor jarak dan motor servo

Prosedur pengujian:

1. Download program yang telah dibuat ke Arduino board : Setelah program sudah ditulis pada Arduino IDE langkah selanjutnya untuk mengunggah program ke Arduino board.

2. Memastikan semua perangkat bekerja : Setelah program kita upload ke Arduino board maka kita akan mengecek kondisi semua peripheral apakah berfungsi dengan baik.

3. Mulai menghidupkan perangkat 
Tabel 1. Hasil pengujian software keseluruhan

\begin{tabular}{|c|c|c|c|}
\hline Pengujian & Diharapkan & Pengamatan & Kesimpulan \\
\hline Start project & $\begin{array}{l}\text { project /software ber- } \\
\text { jalan lancar }\end{array}$ & $\begin{array}{l}\text { Proses berjalanya project } \\
\text { lancar tanpa error }\end{array}$ & Baik \\
\hline $\begin{array}{l}\text { Pembacaan jarak } \\
\text { sensor jarak } 1 \\
\text { dalam } 30 \mathrm{~cm} \\
\end{array}$ & $\begin{array}{l}\text { Sensor bekerja sesuai } \\
\text { dengan jarak yang di } \\
\text { tentukan }\end{array}$ & $\begin{array}{l}\text { Sensor bekerja sesuai } \\
\text { dengan jarak yang di ten- } \\
\text { tukan }\end{array}$ & Baik \\
\hline $\begin{array}{l}\text { Pergerakan mo- } \\
\text { tor servo }\end{array}$ & $\begin{array}{l}\text { Motor servo bergerak } \\
90^{\circ} \text { derajat ketika } \\
\text { sensor mendeteksi } \\
\text { benda }\end{array}$ & $\begin{array}{l}\text { Motor servo bergerak } 90 \circ \\
\text { derajat ketika sensor jarak } \\
1 \text { mendeteksi benda dalam } \\
\text { radius } 30 \mathrm{~cm}\end{array}$ & Baik \\
\hline $\begin{array}{l}\text { Pembacaan jarak } \\
\text { sensor } 2 \text { dalam } \\
15 \mathrm{~cm} \\
\end{array}$ & $\begin{array}{l}\text { Sensor bekerja sesuai } \\
\text { dengan jarak yang di } \\
\text { tentukan }\end{array}$ & $\begin{array}{l}\text { Sensor bekerja sesuai } \\
\text { dengan jarak yang di ten- } \\
\text { tukan }\end{array}$ & Baik \\
\hline $\begin{array}{l}4 \text { LED dan buzzer } \\
\text { menyala }\end{array}$ & $\begin{array}{l}4 \text { LED dan buzzer } \\
\text { menyala ketika sensor } \\
\text { jarak } 2 \text { mendeteksi } \\
\text { benda }\end{array}$ & $\begin{array}{l}4 \text { LED dan buzzer menyala } \\
\text { ketika sensor jarak } 2 \\
\text { mendeteksi benda dalam } \\
\text { radius } 15 \mathrm{~cm}\end{array}$ & Baik \\
\hline
\end{tabular}

Setelah program telah diunggah dan semua perangkat sudah di pastikan berfungsi, Maka selanjutnya adalah melakukan uji coba pada project yang akan kerjakan.

Dengan cara mulai untuk membuang sampah dengan mendekati tempat sampah ketika kita mendekat maka sensor jarak 1 Akan mendeteksi dan akan membuka tutup tempat sampah.

Ketika tempat sampah penuh maka sensor jarak 2 akan membaca volume ketinggian sampah dan akan membunyikan buzzer dan LED secara bersamaan.

\section{Pengujian Hardware}

Pengujian keseluruhan sistem adalah tahapan dimana dilakukan pengujian hardware yang selesai diprogram dan diuji secara keseluruhan mulai dari sistem kerja sensor HC-SR04, motor servo, buzzer, LED dan komponen pendukungnya.

Pengujian dilakukan berdasarkan sesuai kerja hardware. Berikut ini adalah uji coba saat sensor HC-SR04 (1) mendeteksi adanya objek mendekat, ketika jarak tidak lebih dari $30 \mathrm{~cm}$ otomatis motor servo bekerja sehingga pintu tempat sampah membuka dengan sendirinya seperti yang terlihat pada Gambar 9.

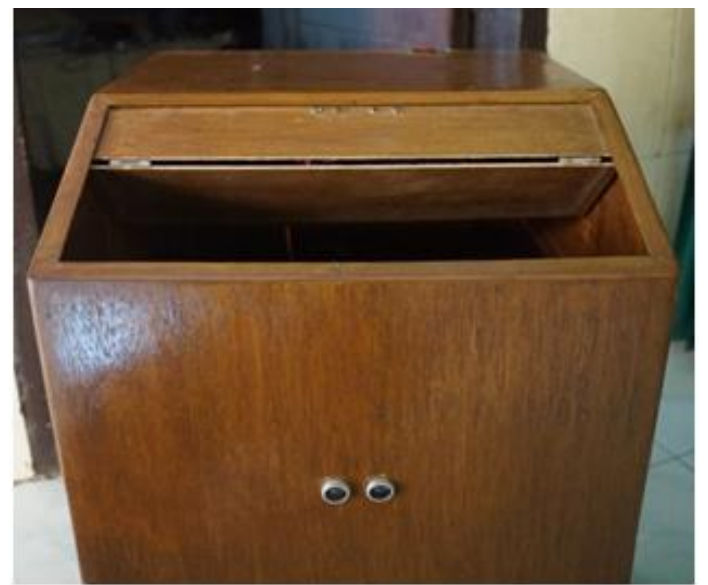

Gambar 9. Pengujian Buka pintu Smart Trash Bin
Keadaan ini terlihat pintu akan tetap terbuka selama objek pada jangkauan jarak tidak melebihi batas dari $30 \mathrm{~cm}$. Hal ini dikarenakan mikrokontroler sudah diprogram untuk sensor HCSR04 (1) akan mengirimkan gelombang ultrasonik dengan jangakuan jarak $30 \mathrm{~cm}$, sehingga saat terhalang objek dengan jarak tidak melebihi $30 \mathrm{~cm}$ gelombang pantul akan ditangkap pin echo pada sensor HC-SR04. Namun jika objek menjauh tidak dalam jangkauan maka pintu Smart Trash Bin akan tertutup secara otomatis seperti yang terlihat pada Gambar 10.

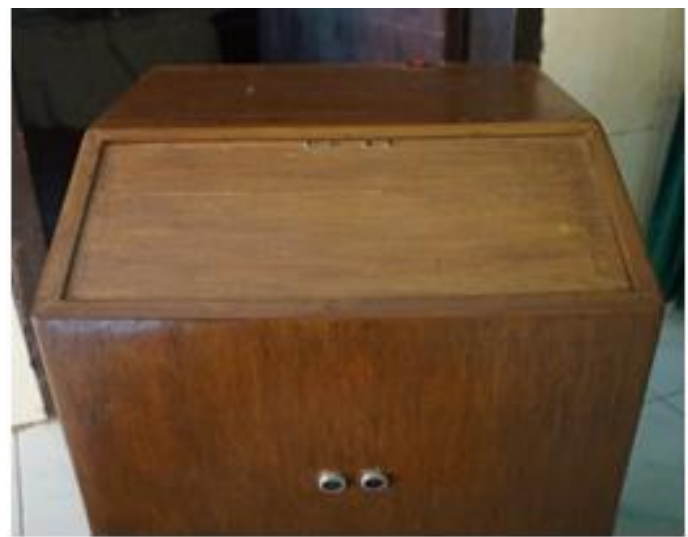

Gambar 10. Pengujian Tutup Pintu Smart Trash Bin

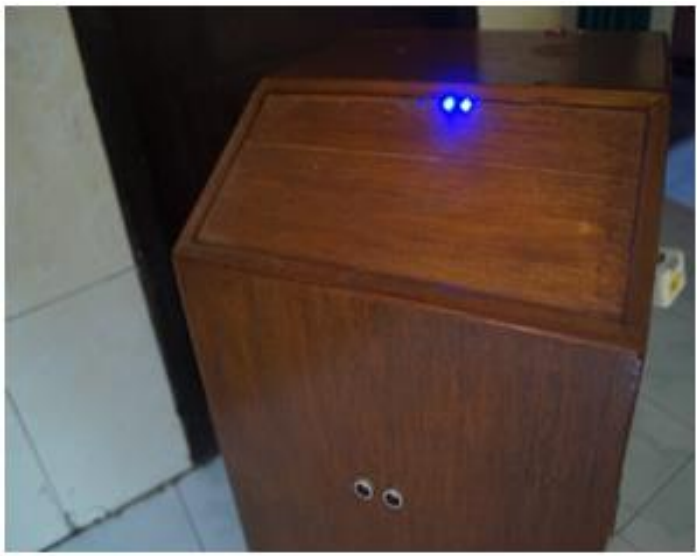

Gambar 11. Pengujian Notifikasi Sampah Penuh 
Berikutnya adalah ketika keadaan sampah penuh sensor HC-SR04 (2) yang terdapat dalam Smart Trash Bin mendeteksi adanya jarak objek mendekat, sehingga buzzer dan LED bekerja sebagai notifikasi bahwa sampah yang ada di dalam sudah penuh dapat diambil dan dibuang dengan efisien. Pengujian notifikasi sampah penuh dapat dilihat pada Gambar 11 .

Dalam kondisi tersebut ketika sampah penuh secara otomatis mekanik buka dan tutup pintu otomatis akan menutup tidak bisa terbuka, sampai sampah yang penuh ada didalam dibersihkan atau dibuang.

\section{PENUTUP}

Setelah dilakukan pengujian dari tempat sampah pintar (smart trash bin) berbasis Arduino UNO ini ternyata skecth pada Arduino IDE berjalan dengan lancer. Arduino Board berkomunikasi dengan hardware dan mengendalikan alat agar berjalan sesuai algoritma program dan sistem kerja dari tempat sampah pintar (smart trash bin) bekerja sesuai dengan urutan intruksi pemrograman dengan menggunakan bahasa C. Koneksi sensor 1 dan sensor 2 dengan Arduino Board dapat bekerja dengan baik, sesuai dengan urutan program Arduino IDE. Servo berputar dengan baik dan benar sesuai sudut derajat yang di intruksikan di program Arduino IDE. Buzzer dan LED bekerja dengan baik sesuai yang diintruksikan pada program Arduino.

Agar perangkat tersebut bisa digunakan in door maupun out door maka diperlukan sebuah solar cell untuk menampung energi tanpa menggunakan jaringan listrik fixed. Untuk lebih efisien lagi maka diperlukan sebuah perangkat/modul tambahan yang dimana ketika tempat sampah penuh maka akan otomatis bisa mengirim pesan singkat melalui SMS (Short Message Service) agar dapat menyampaikan pemberitahuan kepada pegawai kebersihan. Serta untuk mengurangi kerusakan maka perlu perhatian khusus.

\section{DAFTAR PUSTAKA}

Hatta, M., \& Susrama, I. G. (2017). Counting Sperma Aktif Menggunakan Metode Otsu Threshold dan Local Adaptive Threshold. Teknika: Engineering and Sains Journal, 1(1), 47-54.

Istiyanto, J. (2014). Pengantar Elektronika dan Instrumentasi, Pendekatan Project Arduino dan Android (I, 1st Published ed.). Yogyakarta: Andi Publisher.

Kadir, A. (2013). Panduan Praktis Mempelajari Aplikasi Mikrokontroler Dan Pemrogramannya Menggunakan Arduino (I, 1st Published ed.). Yogyakarta: Andi Publisher.

Kadir, A. (2015). From Zero to a Pro: Arduino (I, 1st Published ed.). Yogyakarta: Andi Publisher.

Kadir, A. (2017). Pemrograman Arduino Menggunakan ArduBlock (I, 1st Published ed.). Yogyakarta: Andi Publisher.

Sanjaya, M. (2016). Panduan Praktis Membuat Robot Cerdas Menggunakan ARDUINO dan MATLAB (I, 1st Published ed.). Yogyakarta: Andi Publisher.

Sanjaya, M. (2016). Robot Cerdas, Berbasis Speech Recognititon Menggunakan Matlab Dan Arduino+cd (I, 1st Published ed.). Yogyakarta: Andi Publisher.

Sanjaya, M. (2017). Panduan Praktis Pemrograman Robot Vision Menggunakan Matlab (I, 1st Published ed.). Yogyakarta: Andi Publisher.

Santoso, H. (2015). Panduan Praktis Arduino untuk Pemula. Trenggalek: Elang Sakti.

Syahwil, M. (2014). Panduan Mudah Simulasi Dan Praktek Mikrokontroler Arduino (I, 1st Published ed.). Yogyakarta: Andi Publisher.

Syahwil, M. (2017). Panduan Mudah Belajar Arduino Menggunakan Simulasi Proteus (I, 1st Published ed.). Yogyakarta: Andi Publisher.

Wiraghani, S. R., \& Prasnowo, M. A. (2017). Perancangan dan Pengembangan Produk Alat Potong Sol Sandal. Teknika: Engineering and Sains Journal, 1(1), 73-76. 


\section{LAMPIRAN}

Script SMART TRASH BIN pada program Arduino IDE :

// \{software smart trash bin berbasis arduino\}

// mendefinisikan pin sensor yang di gunakan pada arduino

\#define pingTrig2 7

\#define pingEcho2 6

\#define pingTrig 5

\#define pingEcho 4

\#define buzzer 2

//membuat nama objek servo untuk mengontrol servo

\#include<Servo.h>

//variabel untuk menyimpan posisi servo

Servo myservo;

void openclose()

\{

long duration, inches, $\mathrm{cm}$;

digitalWrite (pingTrig, LOW) ;

// waktu perjalanan sinyal ultrasonik dalam, inci, senti

delaymicroseconds (2);

digitalWrite(pingTrig, HIGH);

// mengaktifkan pin trigPin dengan memberikan sinyal LOW

ke HC-SRO4 selama 2 microseconds

delaymicroseconds (10);

digitalWrite (pingTrig, LOW) ;

// mengaktifkan pin trigger dengan memberikan sinyal HIGH selama 10 microseconds

I/ membaca waktu yang dibutuhkan sinyal ultrasonic dari transmiter $\mathrm{HC}-\mathrm{SRO} 4$

// untuk kembali ke receiver pada sensor HC-SRO4 dalam microsecond

duration = pulseIn (pingEcho,HIGH);

I/ menghitung jarak berdasarkan waktu perjalanan sinyal ultrasonic

$\mathrm{cm}=$ duration / $29 / 2$;

// convert ke cm

// sentimeter samadengan jarak

if $(\mathrm{cm}<10)$

\{

myservo.write(90);

// jika jarak lebih kecil dari 10

delay (100);

Else

I/ maka servo akan bergerak 90 derajat/berlawanan arah jarum jam dengan delay 100

l/ jika tidak maka akan kembali dalam patau 0 dalam delay 1000

myservo.write (0);

delay(1000):

\}

void ligthing(

\{

digitalWrite (buzzer,HIGH) ;

digitalWrite (8,HIGH)

digitalWrite (9,HIGH);

delay(300);

digitalWrite $(8$, LOW) ;

digitalWrite $(9$, LOW) ;

digitalWrite (10,HIGH);

digitalWrite (11,HIGH);

delay (300);

digitalWrite $(10$, LOW)

digitalWrite (11,LOW) ;

delay(300);

void setup ()

\{

Serial.begin(9600);

pinMode (pingTrig2, OUTPUT) ;

pinMode (pingEcho2, INPUT) ;

pinMode (8,OUTPUT) ;

pinMode (9, OUTPUT) ;

pinMode (10, OUTPUT) ;

pinMode (11, OUTPUT) ;

pinMode (buzzer, OUTPUT);

pinMode (pingTrig, OUTPUT);

pinMode (pingEcho, INPUT);

myservo.attach (3);

// memberikan sinyal high pada buzzer

// memberikan sinyal high pada port/pin 8

// memberikan sinyal high pada port/pin 9

// dalam delay 300

// memberikan sinyal low pada port/pin 8

// memberikan sinyal low pada port/pin 9

// memberikan sinyal high pada port/pin 10

// memberikan sinyal high pada port/pin 11

// dengan delay 300

// memberikan sinyal low pada pin/port 10

// memberikan sinyal low pada pin/port 11

// dalam delay 300

// membuka serial port, mensetting kecepatan data ke 9600 bps

// mengkonfigurasi pin triger 2 menjadi output

// mengkofigurasi pin echo 2 menjadi input

// mengkonfigurasi pin 8 menjadi output

// mengkonfigurasi pin 9 menjadi output

// mengkonfigurasi pin 10 menjadi output

// mengkonfigurasi pin 11 menjadi output

// mengkonfigurasi buzzer menjadi output

// mengkonfigurasi pin trigger menjadi output

// mengkofigurasi pin echo menjadi input \}

// objek serfo diletakkan pada pin 3 
Sukarjadi, dkk / Teknika : Engineering and Sains Journal, Vol. 1, No.2, Desember 2017, 101-110

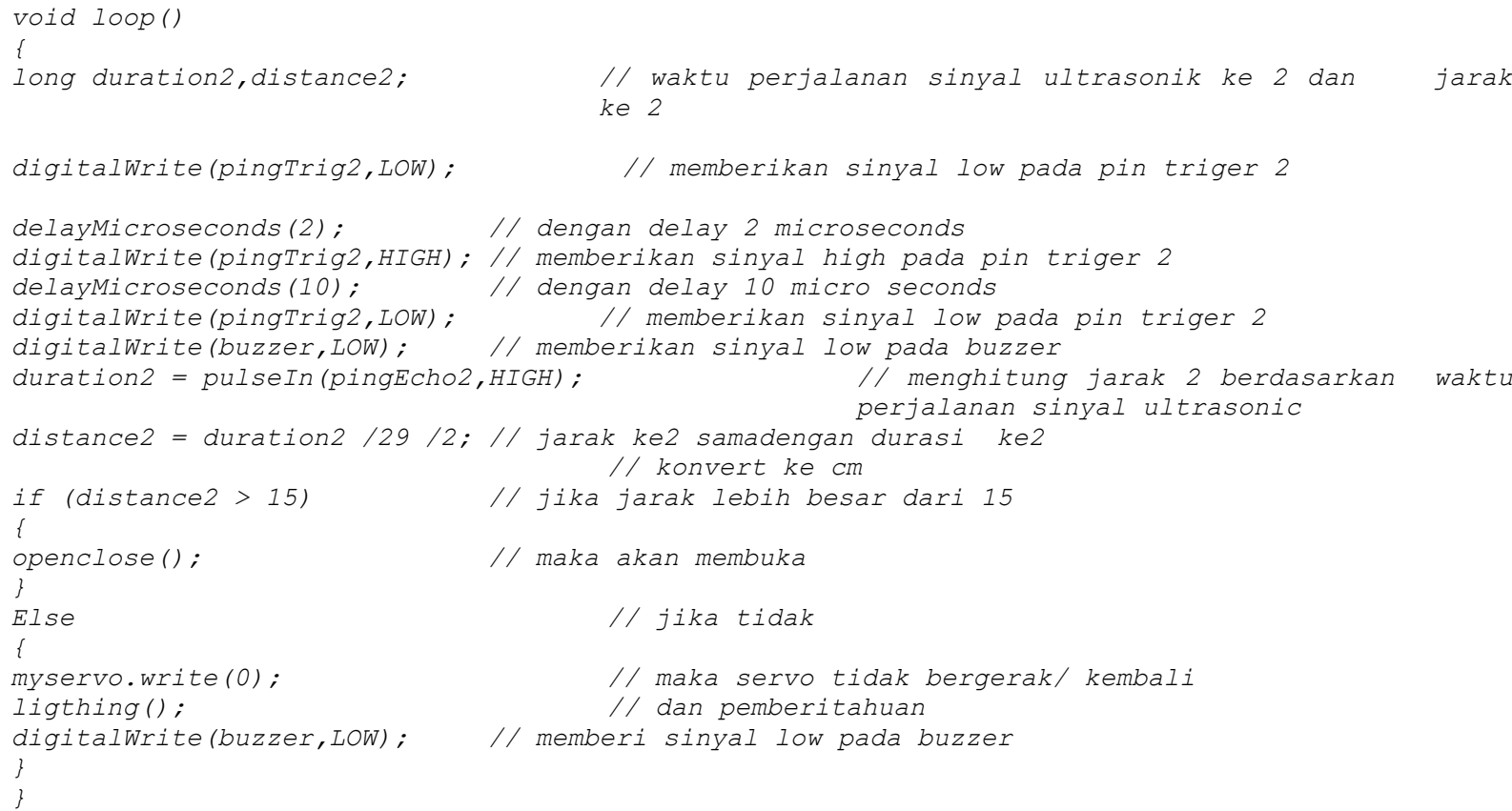


Sukarjadi, dkk / Teknika : Engineering and Sains Journal, Vol. 1, No.2, Desember 2017, 101-110

Halaman ini sengaja dikosongkan 